\title{
Newspaper Coverage of Environmental Issues in the Western Ghats as Audience Perceive
}

\author{
VARNA .M \\ Research Scholar, \\ Department of Journalism and Mass Communication \\ Kuvempu University, Shankarghatta-577451 Karnataka, India. \\ Pro. D.S. POORNANANDA \\ Professor, \\ Department of Journalism and Mass Communication \\ Kuvempu University, Shankarghatta-577451 Karnataka, India.
}

\begin{abstract}
Environmental issues pertaining to the degradation of the Western Ghats are being debated more frequently in the recent past. Much of the debate is taking place in mass media. Studies have indicated that mass media play a pivotal role in shaping the perception of the public about environmental issues. A survey was conducted in Shimoga and Uttara Kannada districts to analyze the readers' perception regarding print media coverage of environmental issues in the Western Ghats. The Western Ghats of India are often regarded as one of the world's 34 'biodiversity hotspots. The Ghats contain more than 30 percent of India's rich sources of flora, fauna, mammal species and flowing rivers and incredible topographical features. Large-scale deforestation, mining and industrial activities in the region have raised concern among the environmentalists and ordinary citizens. The region has seen witnessed vibrant environmental activism in the last four decades. The present study found that the newspaper reports constituted a major source of information on environmental issues for the readers.
\end{abstract}

Keywords: Environmental issues, Western Ghats, Reader's perception.

DOI: $10.7176 / \mathrm{NMMC} / 79-03$

Publication date: April $30^{\text {th }} 2019$

\subsection{Introduction}

The magnificent Western Ghats mountain range is next only to Himalayas and is a biological treasure trove with a high degree of endemism (11 to 78 percent) and scenic beauty. This unique eco-system has been threatened by continuously increasing habitat pressures and declared as one of the world's hottest hotspots of biodiversity. Realizing the need to protect and rejuvenate the ecology and for sustainable development in Western Ghats the Ministry of Environment and Forests (MoEF) constituted the Western Ghats Ecology Expert Panel (WGEEP). The mandate of WGEEP was to demarcate ecologically sensitive zones and suggest measures to conserve protect and rejuvenate the ecology of Western Ghats region.

The central government took some measures for the protection of Western Ghats, in 2012 . The Kasturirangan panel which was set up to study the Gadgil committee report on the Western Ghats recommended prohibition on developmental activities in 37 percent of natural forest that has been identified as ecologically sensitive area.

\subsection{Media and environmental issues}

Media are very important sources of information to the public. They play a very significant role in fulfilling the goals of sustainable development by informing, educating and sensitizing the public. It is again the mass media which often create higher awareness about environmental issues (Poornananda, 2008:30).

A widespread recognition of the environment as an issue by the Western media was noticed in the early 1970s during the celebration of the Earth Day. By the time the UN conference on Human Environment was held in 1972 in Stockholm, there was a considerable rise in press coverage of the environmental issues in the West. Mass media coverage in the West led to a rise in public awareness about the environment.

The role played by mass media in the social construction of environmental problems is named by Hannigan (1995) as "environmental education," which means creating awareness about environmental problems, their consequences and potential remedies. Because environmental issues are related to economic development they become controversial sometimes (Dunlap, 1975) and are more likely to be socially constructed by people in power including political and interest groups (Ader 1995). Several studies have shown that media's agendasetting effect is strongly demonstrated on environmental issues.

The rise and decline of people's concern about our environmental problems is closely related to the media agenda. Hannigan (1995) points out that public concern is partially independent of actual environmental deterioration and is shaped by factors like the extent of mass media coverage because the media clearly dominate 
as sources of information about environmental pollution, while personal sources, such as friends, rank further below (Murch 1971). People obtain most of their political, economic and scientific information from the media, especially television and daily newspapers, which tell them how important an issue is, instead of from real world cues (Ader 1995, Boykoff and Rajan 2007).

\section{Review of literature}

The studies on readers' perception of media coverage of environmental issues are sparse. These studies have focused more on the coverage than the perception of coverage. Antilla, L.(2005) studied the US newspaper coverage of scientific findings relating to climate change and analyzed newspaper reports and news service sources used.

An analysis of US newspaper coverage of climate issues was carried out to comparatively examine mediacreated themes and frames using a social constructivist approach. The study found a reflexive comparison with attendant wire stories and scientific texts. Special attention was given to articles constructed with and framed by rhetoric emphasizing uncertainty, controversy and climate skepticism.

Kakade et al., (2013) examined the role of media in creating awareness about the climate change in Bijapur city. The study found that a majority of the respondents $(60 \%)$ believed that the coverage of climate change issues was relevant and that as much as 86.67 percent of the them got complete information regarding climate change through media. The study found that the communication of climate change from scientists and policymakers to the public through the mass media plays a vital role in public understanding of a global environmental issue.

In his content analysis of The New York Times, the Danish daily Politiken, The Daily Star and L'Orient le Jour (Lebanon) newspapers Eskjaer (2013) found that global perspectives and national approaches dominated climate change communication reflecting the global nature of climate change as well as the traditional research focus of national media systems. The comparative content analysis of climate change coverage in three geocultural regions-The Middle East, Scandinavia, and North America-found a link between global climate change communication and regional media systems. The study found that regional variations in climate change communication carry important communicative implications concerning perceptions of climate change relevance and urgency.

Maxwell \& Boykoff (2008) analyzed coverage about climate change in four UK tabloid newspapers-The Sun (and News of the World), Daily Mail (and Mail on Sunday), The Daily Express (and Sunday Express), and the Mirror (and Sunday Mirror) - which had circulations ten times more than those of broadsides. Between 2000 and 2006 they found that news articles on climate change were predominantly framed through weather events, charismatic mega fauna and movements involving political actors and rhetoric. There were very few stories focused on climate justice and risk. The headlines were filled with tones of fear, misery and doom. The study throws light on discussions of how these representations may influence on going climate science and governance interactions.

Ungar (1999) examined the coverage of extreme weather events in three major U.S. television networks$A B C, C B S$, and $N B C$. The study revealed that there was no association between coverage of climate change and the overall coverage of extreme events. While extreme events had attracted more stories in the U.S., there had been no increase in the coverage devoted to extreme events in foreign countries. The possible effects of shifts in TV coverage on the public salience and understanding of climate change were indicated.

The review of literature showed that climate change issues and the diverse environmental issues were covered by the newspapers. Newspapers made significant contribution towards setting the environmental agenda. There were regional inequalities in the coverage of environmental reporting. That sources influence framing of environmental news was evident in some studies.

\section{Objectives}

The general objective of the study is to examine how the Indian national dailies cover the environmental issues related to the Western Ghats. The specific objectives of the study are (1) to study reader's perception regarding newspaper coverage of environmental issues of the Western Ghats and (2) to analyze the perception of importance given to specific issues of the Western Ghats

\section{Methodology}

The Western Ghats are spread across the ten districts of Karnataka such as Dakshina Kannada, Udupi, Hassan, Chikmagalur, Uttara Kannada, Kodagu, Shimoga, part of Mysore, Chamarajanagar and Belgaum. The present survey was carried out in Shimoga and Uttara Kannada districts where large scale displacement of population has taken place due to several 'development' projects. These two districts have also witnessed active environmental movement in the last three decades. Two taluks from each of the districts were selected for the survey. In each taluk two villages were selected. A total 240 respondents, 120 from each district were selected 
for the survey (Table 1).

Table 1: Sample from the two districts

\begin{tabular}{|c|c|l|l|}
\hline District & Taluk & Village & $\begin{array}{l}\text { Number of } \\
\text { Respondents }\end{array}$ \\
\hline \multirow{3}{*}{ Shimoga } & \multirow{2}{*}{ Hosanagara } & Savanthru & 30 \\
\cline { 3 - 4 } & & Haridravathi & 30 \\
\cline { 3 - 4 } & \multirow{2}{*}{ Sagar } & Kudigere & 30 \\
\cline { 3 - 4 } & & Ambargodalu & 30 \\
\hline \multirow{3}{*}{$\begin{array}{l}\text { Uttara } \\
\text { Kannada }\end{array}$} & \multirow{2}{*}{ Joida } & Terali & 30 \\
\cline { 3 - 4 } & \multirow{2}{*}{ Karwara } & Godashet & 30 \\
\cline { 3 - 4 } & & Kaiga & 30 \\
\cline { 3 - 4 } & & Nagekove & 30 \\
\hline
\end{tabular}

Shivamogga district is situated more or less in the mid south-western part of Karnataka with tropical forests, hilly areas, several lakes and river valleys. Shimoga is an important tourist destination and has industrial, commercial, fine arts and educational centers. Of the seven taluks in the district two taluks-Hosanaga and Sagara- which are part of the Western Ghats were chosen for the survey.

Hosanagara taluk is in the windward side of Western Ghats and is surrounded by Sagar taluk, Tirthahalli taluk, Kundapura taluk of the Udupi district towards west, Shikarpur taluk towards north. It has 30 gram panchayats. According to 2011 India Census the taluk has a population of 118220 with a literacy rate of 79.89 percent. The taluk is covered by dense forest and a sizeable area is covered by the backwater of Linganamakki dam built across Sharavathi River. The average rainfall in the taluk ranges between $3000-8000 \mathrm{~mm}$. With a rainfall of $8000 \mathrm{~mm}$ in a year Hulikal town is the wettest place in the state. The two villages chosen for the survey in the district are Haridravathi and Savanthur.

Haridravati village has a population of 736 as per Census 2011. This village has 75.92 percent literacy which is higher than the slightly higher than the state average. Savanthur has a population of 629 and a literacy rate of 70.92 percent which is lower than the state literacy.

Sagara taluk has a population of 206319 and a literacy of 81.01 percent which is higher than the state average. The taluk consists of 972 villages and 39 Panchayats. Located in the Western Ghats range it has forests and water bodies. The world famous Jog Falls is located in this taluk. With Sharavathi Wildlife Sanctuary and historical places like Keladi and Ikkeri. Sagara taluk is a major tourist destination in the state. The taluk is surrounded by Soraba, Hosanagara and Shikaripur taluks. Kudigere and Ambaragodlu villages in the taluk were selected for the survey.

Kudigere has a population of 472 with a literacy rate of 71.43 percent as per census 2011 . The main occupation of village is agriculture. Ambaragodlu has population of 175 with 84.76 percent literacy.

Uttara Kannada district is one of the biggest districts of Karnataka State with abundant natural resources. The district has varied geographical features with thick forest, perennial rivers and abundant flora and fauna and a long coastal line. According to the 2011 census Uttara Kannada has a population of 1,436,847 with a literacy rate of district has 84 percent. The important Hydro Electric Power Projects are Supa dam, Kadra dam, Kodasalli and Gerusoppa dam along with their generating units besides Kaiga Nuclear Power Project. The district consists of 11 taluks with 208 Gram Panchayats and 1289 Villages. Out of the eleven taluks in the district two taluks - Joida and Karwara - which are part of the Western Ghats were chosen for the survey.

Joida taluk is a small town in the Uttara Kannada district; Joida is also called Supa by locals. Joida comes under Ansi Tiger Reserve Area; this reserve area is one of the 30 Tiger reserve areas in India and Joida taluk has lowest population among all taluks of the Karnataka State. Joida village has a population of 3452 according to the 2011 census. Several dams have been constructed across Kali River for generating hydel power. There have been agitations to save Kali River as its course has been affected by a series of dams across it. The two villages chosen for the survey in the district are Terali and Godashet.

Terali village has a population of 286, and a literacy rate of 65.4 percent, according to the 2011 census. Godashet village has a population of 381 as per the census of 2011 with a literacy of 83.48 percent.

Karwar is the district headquarters of Uttara Kannada district and also a taluk. It is situated between Sahyadri ever green forest in east, blue Arabian Sea to the west. It is one of the green cities of India where eco-tourism is being promoted. A hill has created a natural harbour with protection against wind and sea tides. Being a port town, Karwar is a center for fish business and agriculture. It has a population of 1, 55,213 and a literacy rate of 81.46 percent. Nagekove and Kaiga villages in the taluk were selected for the survey.

Nagekove village has a population of 523 as per census of 2011 and a literacy rate of 76.65 percent. Kaiga village has a population of 238 and a literacy rate of 63.59 percent. The nuclear power generating station which has been in operation since March 2000 was the centre of controversy as several environmental groups had 
opposed setting up of the project in an Eco sensitive region.

The Western Ghats are not only home to the rich biodiversity, but also include areas of high human population density affecting the habitat integrity of the Western Ghats. In the recent decades the Government has taken serious measures to conserve the fast declining biological diversity with the establishment of Protected Area network, tiger reserves and biosphere reserves. More recently a significant new initiative has been added to the conservation efforts in the form Ecologically Sensitive Areas. These areas are not just about regulation of development but are also intimately linked to positive promotion of environment-friendly and socially inclusive development. The sampled villages are located in the ecologically sensitive area of the Western Ghats.

Collected data was entered into the coding sheet and from there into the SPSS software. Cross tables were prepared using the collected data from the questionnaire for analysis.

\section{Results and discussion:}

The respondents mostly read Kannada newspapers. Figure 1 shows that, Vijaya Karnataka has the highest (50percent) readership among the newspapers. The paper's special supplement dedicated to the local news is possibly the reason for its wide readership in the two districts. Somuyktha Karnataka which has wider circulation in Uttara Kannada district has the second highest readership of 24.20 percent.

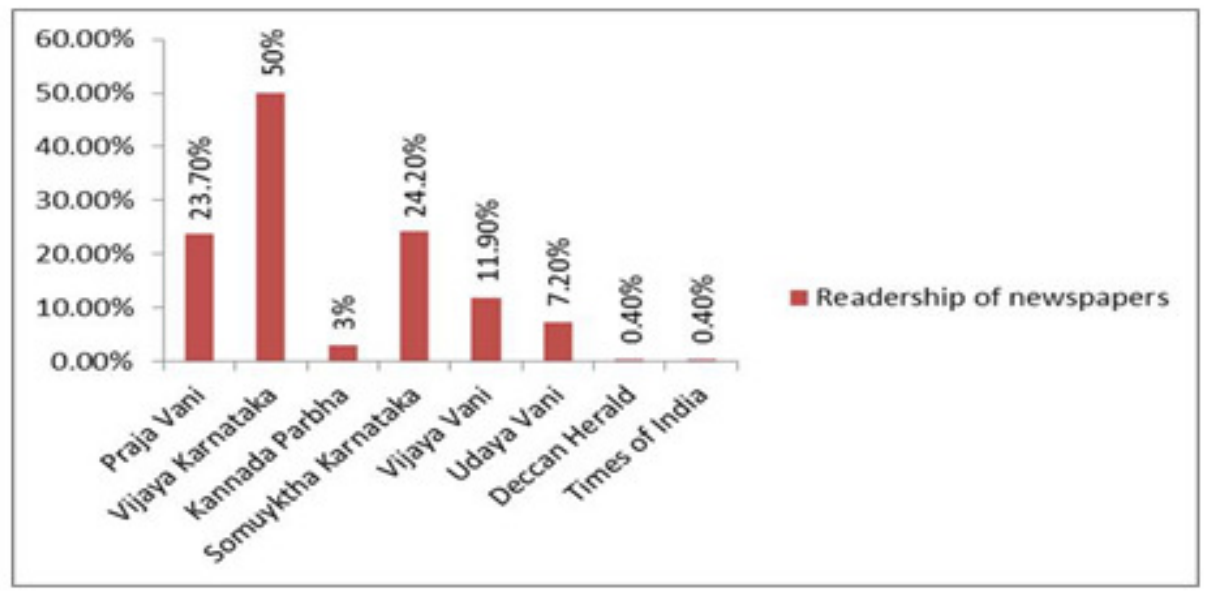

Figure 1: Readership of newspapers

PrajaVani secured the third place with readership of 23.70 percent. It has managed to maintain an independent position, despite an increasingly polarized media landscape in Karnataka. Vijaya Vani secured the fourth place with 12 percent. Udaya Vani which is the most widely circulated newspaper in Dakshina Kannada with a strong regional identification is has a readership of 7.20 percent. Kannada Prabha has the lowest (3 percent) readership in Western Ghats districts.

English newspapers have very low readership. The Deccan Herald and The Times of India which have readership throughout the state have a readership of only 0.4 percent each in the districts of the Western Ghats.

Table 2: Coverage of environmental issues

\begin{tabular}{|c|c|c|}
\hline Environmental news coverage & Number & Percent \\
\hline More than adequate & 4 & 1.7 \\
\hline Adequate & 94 & 39.2 \\
\hline Less than adequate & 142 & 59.2 \\
\hline Total & 240 & 100 \\
\hline
\end{tabular}

A majority of the respondents $(59.2$ percent) believe that the coverage of environmental news in the newspapers is less than adequate (Table 2). Nearly 39.2 percent of the respondents believed that environmental news is adequate. Only a small percent (1.7 percent) of the respondents view environmental news in the dailies as more than adequate. None of the respondents believe that the coverage of environmental issues in the Western Ghats is negligible. It is clear that the respondents do not distrust media with regard to environmental news.

What is reported in environmental news reports in often contested. To what extent the respondents believe in what media report as environmental is the moot question. A majority of the respondents (69.2 percent) think that news about the environmental issues of the Western Ghats is truthful some of the time (Table 3). As much as 15.8 percent of the respondents think that environmental news is truthful most of the time. Only 12.1 percent of the respondents believe that environmental news is rarely truthful. The percent of the respondents who think that environmental news is truthful all of the time is only 2.1. Only two out of 240 respondents are of the view that newspapers never give truthful environmental news. 
Table 3: Truth in environmental news

\begin{tabular}{|l|l|l|l|l|l|l|}
\hline Age & All of the time & Most of the time & Some of the time & Rarely & Never & Total \\
\hline $18-30$ & 2 & 14 & 74 & 12 & 1 & 103 \\
& $(1.9 \%)$ & $(13.6 \%)$ & $(71.8 \%)$ & $(11.7 \%)$ & $(1 \%)$ & $(100 \%)$ \\
\hline $31-50$ & 2 & 17 & 65 & 14 & 1 & 99 \\
& $(2 \%)$ & $(17.2 \%)$ & $(65.7 \%)$ & $(14.1 \%)$ & $(1 \%)$ & $(100 \%)$ \\
\hline Above 50 & 1 & 7 & 27 & 3 & - & 38 \\
& $(1 \%)$ & $(18.4 \%)$ & $(71.1 \%)$ & $(7.9 \%)$ & & $(100 \%)$ \\
\hline Total & 5 & 38 & 166 & 29 & 2 & 240 \\
& $(2.1 \%)$ & $(15.8 \%)$ & $(69.2 \%)$ & $(12.1 \%)$ & $(0.8 \%)$ & $(100 \%)$ \\
\hline
\end{tabular}

The extent of truthfulness in environmental news and the age of the respondents do no appear to be related. As much as 71.8 percent of the respondents in the age group of 18-30,71.1 percent in age group of above 50, and 65.7 percent of the respondents in the age group of 31-50 think that newspaper coverage of environmental issues in the Western Ghats is truthful some of the time.

As the age of the respondent increases their belief that environmental stories are truthful most of the times also increases. While 13.6 percent of the respondents in the age group of above 18-30 believe that the environmental news is truthful most of the time the percent goes up to 18.4 in case of respondents above 50 years of age.

Whereas 14.1 percent of the respondents in the age group of 31-50 and 11.7 percent of the respondents in the age group of 18-30 express the view that the environmental news is rarely truthful the percent of those above the age of 50 years who agree with them is only 7.9 percent.

Only a negligible percent (1.9 percent and 1 percent) of the respondents in the age group of 18-30 believe that the environmental news in the newspapers is truthful all of the time and never truthful. A very low percent (2) of the respondents in the age group of 31-50 think that newspaper coverage of environmental issues is truthful all of the time. Only 1 percent of the respondents in the age group of above 50 years believed that news coverage of environmental issues is truthful all of the time.

Table 4: Satisfaction about news coverage

\begin{tabular}{|l|l|l|}
\hline Satisfaction of news & Number & Percent \\
\hline Very satisfied & 1 & 0.4 \\
\hline Somewhat satisfied & 111 & 46.3 \\
\hline Neither satisfied nor dissatisfied & 101 & 42.1 \\
\hline Somewhat dissatisfied & 15 & 6.3 \\
\hline Very dissatisfied & 12 & 5 \\
\hline Total & 240 & 100 \\
\hline
\end{tabular}

A majority of the respondents are not dissatisfied with the coverage of the environmental issues of the Western Ghats. While 46.3 percent of the respondents find that media coverage of environmental news is somewhat satisfied, 42.1 percent of them say that they are neither satisfied nor dissatisfied (Table 4). Only a small percentage of them say they are very satisfied ( 0.4 percent), somewhat dissatisfied ( 6.3 percent) and very dissatisfied ( 5 percent) with the coverage of environmental issues in the Western Ghats.

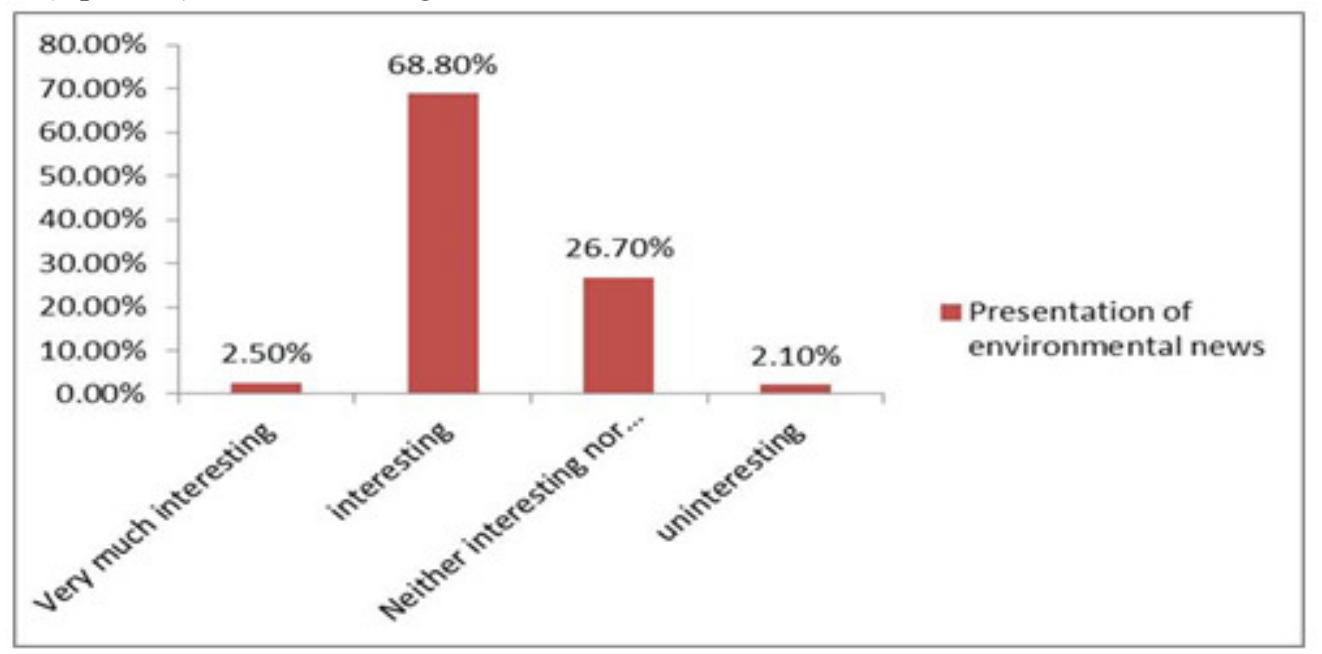

Figure 2: Presentation of environmental news

Figure 2 shows that 68.8 percent of the respondents said that presentation of environmental news in 
newspapers was interesting while as much as 26.7 percent of the respondents said that presentation was neither interesting nor uninteresting. Only 2.5 percent and 2.1 percent of the respondents said that presentation of environmental news in the print media was very much interesting and uninteresting respectively.

A majority of the respondents ( 35.8 percent) believe that independent sources are used in the newspapers to write stories of environmental issues in the Western Ghats (Table 5). This is contrary to the findings of several studies which have shown that official sources are the most dominant sources in environmental news stories. Interestingly officials and experts are not perceived as the sources that are quoted as often as the independent sources.

Table 5: Importance given to environmental news sources

\begin{tabular}{|l|l|l|}
\hline Sources of news & Number & Percent \\
\hline Government/official sources & 54 & 22.5 \\
\hline Scientists/experts & 25 & 10.4 \\
\hline Legal /court & 25 & 10.4 \\
\hline Pressure group/activists & 29 & 12.1 \\
\hline Non-affiliated person & 86 & 35.8 \\
\hline Affected persons & 1 & .4 \\
\hline Politicians & 20 & 8.3 \\
\hline Total & 240 & 100 \\
\hline
\end{tabular}

As much as 22.5 percent of the respondents are of the view that print media get information from government or official sources. Nearly 10.4 percent of the respondents believe that newspaper get primary information from scientist/experts and legal/court sources. Only 12.1 percent of the respondents believe that newspapers gather news about environmental problems from pressure group and activists. The percent of those who believe that politicians are given importance as sources of environmental news is only 8.3. Except one respondent no one else thinks that those affected by the projects in the Western Ghats are quoted in newspapers.

\section{Table 6: Perceived cause of deforestation as reported in newspapers}

\begin{tabular}{|l|l|l|}
\hline $\begin{array}{l}\text { Aspect of } \\
\text { deforestation }\end{array}$ & Number & Percent \\
\hline Felling of trees & 14 & 5.8 \\
\hline Encroachment & 53 & 22.1 \\
\hline Population explosion & 6 & 2.5 \\
\hline Forest fire & 53 & 22.1 \\
\hline Mining & 15 & 6.3 \\
\hline Hydro power project & 61 & 25.4 \\
\hline Roads and railways & 1 & .4 \\
\hline Agriculture & 30 & 12.5 \\
\hline Quarries & 2 & .8 \\
\hline Power lines & 5 & 2.1 \\
\hline Total & 240 & 100 \\
\hline
\end{tabular}

As much as 25.4 percent of the respondents feel that building of hydro power project was the main cause deforestation as reported in newspapers (Table 6). As much as 22.1 percent of the respondents each believe that forest fire and encroachment are the main cause of deforestation as reported in newspapers. Those who think that newspapers have highlighted agriculture as the reason for deforestation constitute 12.5 percent of the respondents. The other causes of deforestation are not given importance in newspapers according to the respondents. Mining and felling of trees are believed to be highlighted in newspapers as the causes of deforestation by 6.3 and 5.8 percent of the respondents respectively. That a majority of the respondents have found hydro power projects as the most often cited reason for deforestation in newspapers reflects the reality that many hydro power projects have been built along the Western Ghats in the state. 


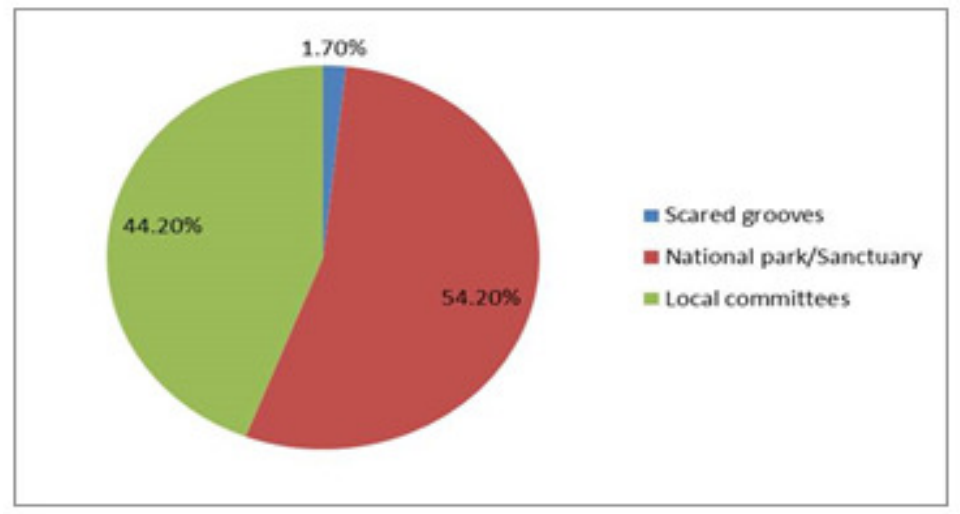

Figure 3: Conservation method reported in newspapers

A majority of the respondents (54.20 percent) are of the view that newspapers have highlighted national park as playing a major role in conservation of forest in the Western Ghats (Figure 3). It should be noted that national parks in the Western Ghats have saved large areas of forests which otherwise would have been destroyed. As much as 44.20 percent of them think that newspapers have focused on local/village committees as the instruments through which forest conservation has taken place in the Western Ghats. Only a negligible percent (1.7 percent) of them are of the view that newspapers have written about protecting sacred grows as the means of conservation of forest.

Table 7: Aspects of mining issue covered

\begin{tabular}{|l|l|l|}
\hline Coverage of mining & Number & Percent \\
\hline Erosion of top soil & 64 & 26.7 \\
\hline Siltation & 18 & 7.5 \\
\hline Deforestation & 110 & 45.8 \\
\hline Threat to wildlife & 46 & 19.2 \\
\hline Polluted stream & 2 & .8 \\
\hline Total & 240 & 100 \\
\hline
\end{tabular}

One of the recent environmental controversies of Western Ghats has been mining. As much as 45.8 percent of the respondents have the perception that deforestation is the main consequence of mining as reflected in newspaper coverage. Erosion of top soil is another consequence of mining which has been highlighted by newspapers according to 26.7 percent of the respondents (Table 7). Nearly 19.2 percent of the respondents think that newspapers have highlighted threat to wildlife as a major consequence of mining in the Western Ghats. Only 7.5 percent of them are of the view that newspapers have focused on siltation as problem arising out of mining in the Western Ghats. Pollution of the streams in the Western Ghats does not seem to be a major problem reported by newspapers.

One of the biggest issues in the Western Ghats region has been displacement. Several development projects have displaced thousands of families in the Western Ghats region. The persons displaced by these projects have been fighting for compensation, rehabilitation and resettlement for decades. As for as the coverage given to the issue of displacement is concerned as many as 54.6 percent respondents believe that that insufficient compensation has received a greater coverage in the press (Table 8). The process of displacement marked by protests and hunger strike often found itself as news in newspapers.

Table 8: Aspect of the displacement issue highlighted in the press

\begin{tabular}{|l|l|l|}
\hline Aspect of displacement & Number & Percent \\
\hline Loss of land & 40 & 16.7 \\
\hline Insufficient compensation & 131 & 54.6 \\
\hline Unemployment & 52 & 21.7 \\
\hline Lack of proper rehabilitation & 17 & 7.1 \\
\hline Total & 240 & 100 \\
\hline
\end{tabular}

Thus, readers think that insufficient compensation was the most-frequently reported aspect of the issue. Unemployment generated by developmental activities in the regions has been covered by the newspapers according to 21.7 percent of the respondents. Loss of land as a displacement issue is highlighted by newspapers according to 16.7 percent of the respondents. Lack of proper rehabilitation aspect is the least covered aspect (7.1percent) according to the respondents. Respondents think that insufficient compensation received better coverage than unemployment, loss of land and lack of proper rehabilitation aspects. 


Table 9: Perceived importance given to the cause of displacement
\begin{tabular}{|c|c|c|}
\hline $\begin{array}{c}\text { Causes of } \\
\text { displacement }\end{array}$ & Mean & $\begin{array}{r}\text { Rank } \\
\text { order }\end{array}$ \\
\hline Mining & 1.29 & 1 \\
\hline National park & 1.76 & 2 \\
\hline Military base & 2.00 & 3 \\
\hline Hydro power project & 2.11 & 4 \\
\hline Industry & 2.39 & 5 \\
\hline Dam & 2.70 & 6 \\
\hline Tiger project & 3.92 & 7 \\
\hline
\end{tabular}

According to the respondents mining as the cause of displacement received the highest coverage in the dailies, while the respondents identified national park as the problem receiving the second highest coverage in the newspapers. Military base was the issue that received the third highest coverage among the seven issues. Respondents believe that news related hydro power project issue received the fourth highest coverage. Dam, industry and tiger project as the cause of displacement received fifth, sixth and seventh ranks respectively (Table 9).

Table 10: Perceived coverage of displaced persons

\begin{tabular}{|c|c|c|}
\hline Displaced persons & Number & Percent \\
\hline Farmers & 125 & 52.1 \\
\hline Traders & 1 & .4 \\
\hline Landless laborers & 112 & 46.7 \\
\hline Tribes & 2 & .8 \\
\hline Total & 240 & 100 \\
\hline
\end{tabular}

Displacement is one of the issues that have been a subject of debate in the Western Ghats region. Going by what the newspapers have reported a majority of the respondents (52.1 percent) think development projects in the region have displaced farmers (Table 10). As much as 46.7 percent of the persons displaced by development projects in the Western Ghats region were landless labourers as understood by the respondents through coverage in newspapers. Although many of the displaced persons are tribes they do not seem to have figured as victims in the newspapers. Only 2 of them think that tribes are reported as displaced in newspapers. Traders also do not seem to have been presented in newspapers as displaced persons.

Table 11: Readers' response to news on environmental issues

\begin{tabular}{|c|c|}
\hline Response & Number (percent) \\
\hline Letters written & $2(.8)$ \\
\hline Letters Published & - \\
\hline Articles written & $2(.8)$ \\
\hline Articles published & - \\
\hline
\end{tabular}

None of the respondents was able to get any letters or articles published in the newspapers. Only two of them wrote letters to the editor but they were not published. Another two of them wrote articles but they too were not published. The response to the news that appeared on the environmental issues in the Western Ghats appears to be very poor. At the same time there is also an indication that newspapers have positively responded to the concerns of their readers in the two districts (Table 11).

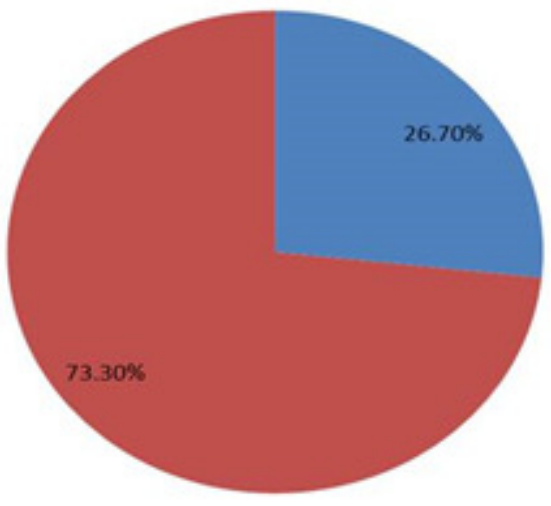

- Participation

= Not-participation

Figure 4: Participation in environment-related activities 
A great majority of 73.33 percent of respondents have not participated in any activity related to environmental protection on account of what they read in newspapers (Figure 4). However, participation of 26.67 percent of the respondents such activities look considerable. The newspapers have succeeded to some extent in people into some kind of action with regard to the environmental issues of the two districts. This is also an indication that what was reported in newspapers was discussed among the newspaper readers as that is essential for any collective action.

Table 12: Sharing of environmental information

\begin{tabular}{|c|c|c|}
\hline $\begin{array}{c}\text { Shared } \\
\text { with others }\end{array}$ & Number & Percent \\
\hline Yes & 51 & 21.3 \\
\hline No & 189 & 78.8 \\
\hline Total & 240 & 100 \\
\hline
\end{tabular}

As many as 21.3 percent of the respondents shared the information they read in newspapers about environmental issues in the Western Ghats with others in their villages. The sharing of information suggests that the two-step flow of information has been operation among the people in the region. The information is not only reaching newspaper readers but also those did not read them but heard from others (Table 12).

\section{Conclusion}

For a majority of the respondents newspapers are the key providers of information on environmental issues. A great majority of them believe that the newspaper stories about environmental issues are truthful only some of the time. Unlike English newspapers Kannada newspapers seem to have paid attention to the interests of the readers in taluks and villages. A majority of the stories were found to be favorable towards environmental causes in the Western Ghats. Non- affiliated persons dominated environmental news in newspapers as sources according to the respondents.

Readers seem to have the impression that there is lack of balance in coverage of environmental issues as they see only some sources dominating the news stories. Among the environmental problems deforestation is seen as a major problem afflicting the Western Ghats region. According to the readers' understanding through newspapers deforestation has been caused mainly by the hydro power projects. While encroachment and forest fire could be reasons for higher coverage of deforestation there is also a view that newspapers do not pay adequate attention to all factors that have led to deforestation in the Western Ghats.

Mining that has caused large scale destruction in the Western Ghats region of which Shimoga and Uttara Kannada districts are a part accounted for only a small percent of the environmental news. Readers seemed to be somewhat satisfied with the coverage given to the environmental problems. Only a negligible number of respondents wrote letters and articles for the newspapers. But none of them was published suggesting lack of understanding on the part of the newspapers with regard to issues that are considered important by the readers. A considerable percent of the respondents took part in the activities related to environmental conservation in the Western Ghats on account of what was reported in newspapers. It is interesting to note that newspapers have succeeded although in a small way in pushing people into some kind of action. Those who read newspapers share information about environmental issues in the Western Ghats with other suggesting that the two-step flow model is in operation in the villages.

These findings indicate that the newspapers have not only provided information about the environmental issues of the Western Ghats but have also influenced them to participate in activities related to environmental protection.

\section{Reference}

Adiga, S \& Poornananda, D.S. (2013).Environmental Movement and the media in DakshinaKannada .Global Media

(1).https://www.caluniv.ac.in/Global\%20mdia\%20journal/ARTICLES_JUNE_2013/ARTICLE-\%204Poornananda.pdf retrieved Sept 24, 2013.

Hussain,.Z \& Ray,.V.(2000).Media and communications in the third world. New Delhi. Academy of third world studies.231-237.

http://www.onefivenine.com/india/villages/Uttar-Kannad/Supa/Joida retrieved January 12, 2018. https://www.census2011.co.in/data/village/602610-kaiga-karnataka.html retrieved January 12, 2018. https://www.census2011.co.in/data/village/602622-nagekove-karnataka.html retrieved January 12, 2018. https://www.census2011.co.in/data/village/602726-joida-karnataka.html retrieved January 12, 2018. https://www.census2011.co.in/data/village/602713-terali-karnataka.html retrieved January 12, 2018. http://citeseerx.ist.psu.edu/viewdoc/download?doi=10.1.1.427.5729\&rep=rep1\&type=pdf retrieved March 25, 2017.

https://www.census2011.co.in/data/village/602722-godashet-karnataka.html retrieved January 1, 2018. 
http://www.onefivenine.com/india/villag/Uttar-Kannad/Karwar retrieved January 12, 2018. http://www.onefivenine.com/india/villag/Uttar-Kannad/Karwar retrieved February 2 12, 2018. http://www.onefivenine.com/india/villag/Shimoga/Sagar retrieved January 12, 2018. http://www.census2011.co.in/data/village/607310-ambaragodlu-karnataka.html retrieved January 12, 2018. http://www.census2011.co.in/data/village/607269-kudigere-karnataka.html retrieved February 23, 2018. http://www.onefivenine.com/india/villages/Shimoga/Sagar/Kudigere retrieved January 12, 2018. http://www.karnatakaholidays.com/hosanagara.php retrieved January 12, 2018. http://www.onefivenine.com/india/villag/Shimoga/Hosanagara retrieved January 12, 2018. https://www.census2011.co.in/data/village/607913-haridravati-karnataka.html retrieved January 12, 2018. https://www.census2011.co.in/data/village/607986-savanthur-karnataka.html retrieved February 27, 2018. http://www.onefivenine.com/india/villages/Shimoga/Hosanagara/Haridravathi retrieved January 12, 2018. http://www.onefivenine.com/india/villages/Shimoga/Hosanagara/Savanthur retrieved January 12, 2018.

http://www.indiaenvironmentportal.org.in/files/Biodiversity $\% 20$ of $\% 20$ Karnataka $\% 20 a t \% 20 a \% 20$ Glance $0 . p d f$ retrieved March 25, 2017.

https://www.wwfindia.org/about_wwf/critical_regions/western_ghats2/about the western_ghats/ retrieved January 12, 2018.

http://www.thehindu.com/todays-paper/tp-in-school/the-western-ghats-biodiversityhotspot/article14403413.ece1 retrieved February 2, 2018.

http://www.iosrjournals.org/iosr-jhss/papers/Vol10-issue1/F01013743.pdf retrieved March 25, 2017. https://www.sciencedirect.com/science/article/pii/S095937800500052X retrieved March 25, 2017. http://iopscience.iop.org/article/10.1088/1748-9326/3/2/024002/pdf retrieved January 12, 2018. http://www.theurbanclimatologist.com/uploads/4/4/2/5/44250401/strangeweather.pdf retrieved January 12, 2018. https://www.wikiwand.com/en/Sagara,_Karnataka retrieved January 12, 2018. https://www.wikiwand.com/en/Karwar, Karnataka retrieved January 2, 2018. http://uttarakannada.nic.in/ retrieved January 12, 2018.

https://www.wikiwand.com/en/Uttara_Kannada retrieved January 12, 2018.

https://www.wikiwand.com/en/Joida retrieved January 12, 2018.

https://www.wikiwand.com/en/Kaiga retrieved January 12, 2018.

https://www.wikiwand.com/en/Shimoga retrieved January 12, 2018.

https://www.karnataka.com/shimoga/ retrieved January 12, 2018.

https://www.wikiwand.com/en/Hosanagara retrieved January 12, 2018.

https://www.wikiwand.com/en/Shimoga district retrieved February 2, 2018.

http://www.moef.nic.in/downloads/public-information/Annexure5-7th.pdf retrieved March 25, 2017.

http://www.moef.gov.in/sites/default/files/2\%20HLWG-Report-Part-2.pdf retrieved February 2, 2018.

Poornananda.D.S. (2008).Claim-makers and frames of Environmental News in the Indian Press. Mass Communicator.3 (2).30-36.

Ramachandra,.T.V \& Vinay,.S. Vishnu. Mukri Naik,. Sreekanth Subash M.D.Rao,.G.R. Shenoy,.H.Surya Prakash. Chandran,. (2013).Kumaradhara River Basin, Karnataka Western Ghats: Need for Conservation and Sustainable Use. http://www.ces.iisc.ernet.in/biodiversity/pubs/ETR/ETR54/ETR54.pdfretrieved 2013, Sept 24. 